\title{
Spawane zbiorniki ciśnieniowe osłabione otworami projektowane według WUDT/UC/2003
}

\author{
Openings weakened welded pressure vessels \\ designed according to WUDT/UC/2003
}

\section{Streszczenie}

W artykule przedstawiono problematykę projektowania zbiorników ciśnieniowych osłabionych otworami w świetle przepisów WUDT/UC/2003. Scharakteryzowano współczynnik osłabienia otworami w zależności od sposobu rozmieszczenia łączników na płaszczu lub dennicy zbiornika. Obliczono współczynniki osłabienia mostkami wzdłużnymi, obwodowymi i skośnymi części walcowej zbiornika. Dokonano analizy współczynników wytrzymałościowych dla wybranych przypadków konstrukcyjnych. Przeprowadzono obliczenia współczynnika osłabienia włazami rewizyjnymi i wyczystkami w części walcowej zbiornika. Określono wpływ osłabienia otworami den wypukłych i płaskich na grubość ich ścianki. Zaprezentowano wytyczne wzmacniania króćców w części walcowej i dennicy zbiornika ciśnieniowego.

Słowa kluczowe: zbiorniki ciśnieniowe, projektowanie konstrukcji, konstrukcje spawane

\section{Abstract}

In this paper issues of designing of pressure vessels weakened by openings in light of WUDT/UC/2003 regulations are presented. Openings weakening coefficient depending on nozzle spacing on vessel shell or head is characterized. Weakening coefficients for longitudinal, circumferential and oblique patterns of cylindrical part of tank are calculated. Analysis of strength reduction coefficients for selected cases of construction is made. Calculation of weakening coefficient for manholes and inspection handholes in tank shell were carried out. Influence of weakening by openings in dished and flat head on the thickness of its walls are determined. Guidelines of nozzle reinforcement in cylindrical part and head of pressure vessel are presented.

Keywords: pressure vessels, design, welded structures

\section{Wprowadzenie \\ - spawane zbiorniki ciśnieniowe z łącznikami}

Urządzenia ciśnieniowe objęte dyrektywami Unii Europejskiej, niezależnie od rodzaju konstrukcji (zbiorniki, wytwornice pary i wody gorącej, rurociągi) i przeznaczenia (rodzaj i grupa medium), zawierają spawane łączniki - odgałęzienia rurowe w postaci króćców, kształtek, włazów lub nakładek

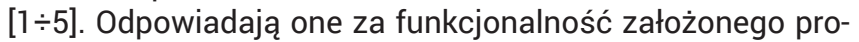
cesu technologicznego, ułatwiają jego kontrolę, a niekiedy zaślepione kołnierzem stanowią rolę włazu lub otworu re-

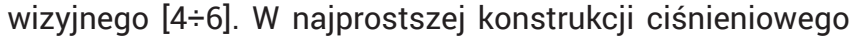
zbiornika walcowego znajdują się przynajmniej dwa króćce, doprowadzający i odprowadzający medium (gaz lub ciecz) z naczynia. Niejednokrotnie jednak urządzenia ciśnieniowe są rozwiązaniami o dużym stopniu skomplikowania, zarówno od strony konstrukcyjnej (niekiedy zespoły składające się z kilku elementów ciśnieniowych z wieloma łącznikami), jak i technologicznej (grubościenne lub kilkupowłokowe naczynia o wysokich parametrach roboczych) $[1 \div 4]$.
Nierzadko są to wykonywane na zamówienie elementy aparatury procesowej, zatem typowy przykład produkcji jednostkowej. W takich przypadkach łączniki często są specjalnej konstrukcji np. dedykowane odlewy lub odkuwki, nie będące wyrobami katalogowymi, które niekiedy dodatkowo mogą być usytuowane pod wymuszonymi warunkami eksploatacyjnymi kątami [4]. Projektant ma oczywiście wybór między prostym technologiczne rozwiązaniem, lokalnie generującym znaczne naprężenia lub, w przypadku trudniejszych warunków eksploatacyjnych, opcją korzystniejszą wytrzymałościowo, ale kosztowniejszą (skomplikowane przygotowanie, wymagane wysokie kwalifikacje spawaczy, wymagana kontrola - badania nieniszczące) [5]. Najkorzystniejszą z technologicznego punktu widzenia sytuacją jest możliwość montażu łączników w płaskiej części zbiornika (np. w dennicy płaskiej), jednak zasadniczo tego typu rozwiązania konstrukcyjne urządzeń ciśnieniowych nie są uzasadnione ekonomicznie [7]. Z uwagi na bezpieczeństwo pracy zbiornika, do spawania łączników należy zastosować technologie zapewniające wysoką jakość spoin. Najczęściej w tym celu stosowane są metody spawania elektrodą otuloną i TIG, ewentualnie dla elementów o większych grubościach

Dr inż. Tomasz Piwowarczyk, inż. Tomasz Nabielec - Politechnika Wrocławska.

Autor korespondencyjny/Corresponding author. tomasz.piwowarczyk@pwr.edu.pl 
ścianki spawanie pod topnikiem, natomiast $\mathrm{z}$ uwagi na możliwość wystąpienia przyklejeń nie zaleca się metody MAG [4]. Poszczególne elementy zbiorników ciśnieniowych należy spawać z pełnym przetopem, jednak w przypadku króćców (szczególnie wpuszczanych) w praktyce często stosuje się spoiny pachwinowe lub czołowe niepełne. Szczegóły technologiczne montażu króćców zawarto w PN-EN 2861:2001 "Proste, nieogrzewane płomieniem zbiorniki ciśnieniowe na powietrze lub azot - Część 1: Zbiorniki ciśnieniowe ogólnego przeznaczenia" oraz WUDT-UC [8].

Zbiornik ciśnieniowy definiowany jest jako powłoka wraz z elementami bezpośrednio przynależnymi, zaprojektowana i zbudowana w celu zawierania płynów pod ciśnieniem, aż do miejsca połączenia z innym urządzeniem $[1 \div 3]$. Każdy otwór $w$ takiej powłoce poddanej działaniu ciśnienia, w połączeniu z często znacznym ciężarem własnym konstrukcji oraz dodatkową masą magazynowanego medium (głównie cieczy), powoduje lokalną koncentrację naprężeń [5]. Naprężenia te, muszą być uwzględnione już na etapie projektowania urządzenia ciśnieniowego. Wiąże się to z koniecznością zwiększenia grubości ścian$\mathrm{ki}$, jednak wykonywanie całego zbiornika z grubszego materiału jest nieekonomiczne, zatem powszechnie stosuje się rozwiązanie alternatywne w postaci pierścieniowych wzmocnień $[4 \div 6,8 \div 11]$.

\section{Formuła obliczeniowa i założenia wstępne}

Scharakteryzowana w [7] formuła obliczeniowa, oprócz określenia zależności kształtowo-wymiarowych głównych składowych zbiorników ciśnieniowych (płaszcza i dennic), pozwala również na analizę ich zachowania w wyniku osłabienia otworami. Równania i tabele użyte $w$ formule obliczeniowej bazują na wytycznych UDT, zawierających wskazówki projektowania urządzeń osłabionych otworami w rozdziale WUDT-UC-WO-O (Wymagania ogólne - Obliczenia wytrzymałościowe) [8]. Do obliczeń wykorzystano w szczególności punkty 01 Elementy walcowe podlegające ciśnieniu wewnętrznemu oraz 08 Dna wypukłe podlegające ciśnieniu od strony powierzchni wklęsłej [8]. Oprócz osłabienia konstrukcji zbiornika ciśnieniowego otworami, projektant powinien uwzględnić również ewentualne osłabienia wynikające z technologii wytwarzania. Przy określeniu współczynników osłabienia otworami oraz spoinami, należy wybrać najniższą z wyznaczonych wartości. Mając na uwadze uproszczenie obliczeń w przeprowadzonych analizach przyjęto współczynnik osłabienia spoinami $z=1$. Materiał wybrany do analiz to stal S355JR, a temperatura obliczeniowa we wszystkich przypadkach wynosiła $20{ }^{\circ} \mathrm{C}$. Obliczenia przeprowadzono dla zbiornika o średnicy 1500 i długości 5000 mm, przy założonym ciśnieniu roboczym $2 \mathrm{MPa}$.

\section{Współczynnik osłabienia otworami}

Współczynnik osłabienia otworami jest uzależniony od sposobu rozmieszczenia otworów na płaszczu zbiornika. W zależności od ich rozstawienia oblicza się go dla mostków wzdłużnych $z_{1}$, obwodowych $z_{2}$, skośnych $z_{z r e d}$ lub dla pojedynczych otworów $z_{o}$ (rys. 1) $[5,8,11]$. W przypadku wyznaczania grubości ścianki dennic, dla każdego rodzaju dna są określone indywidualne wytyczne określające wpływ osłabienia otworem $[8,11]$. Im mniejsza jego wartość, tym bardziej skomplikowany stan naprężeń i większe wymagania odnośnie grubości ścianki. Do obliczeń żądanych grubości ścianki wybiera się najbardziej krytyczny przypadek współczynnika osłabienia z wszystkich analizowanych.

Niezależnie od ilości i wzajemnego układu geometrycznego otworów (mostków), dla każdego z nich z osobna należy obliczyć współczynnik osłabienia pojedynczym otworem $z_{0}$. Zgodnie $z$ [8] wyznacza się go na podstawie tablicy I a)
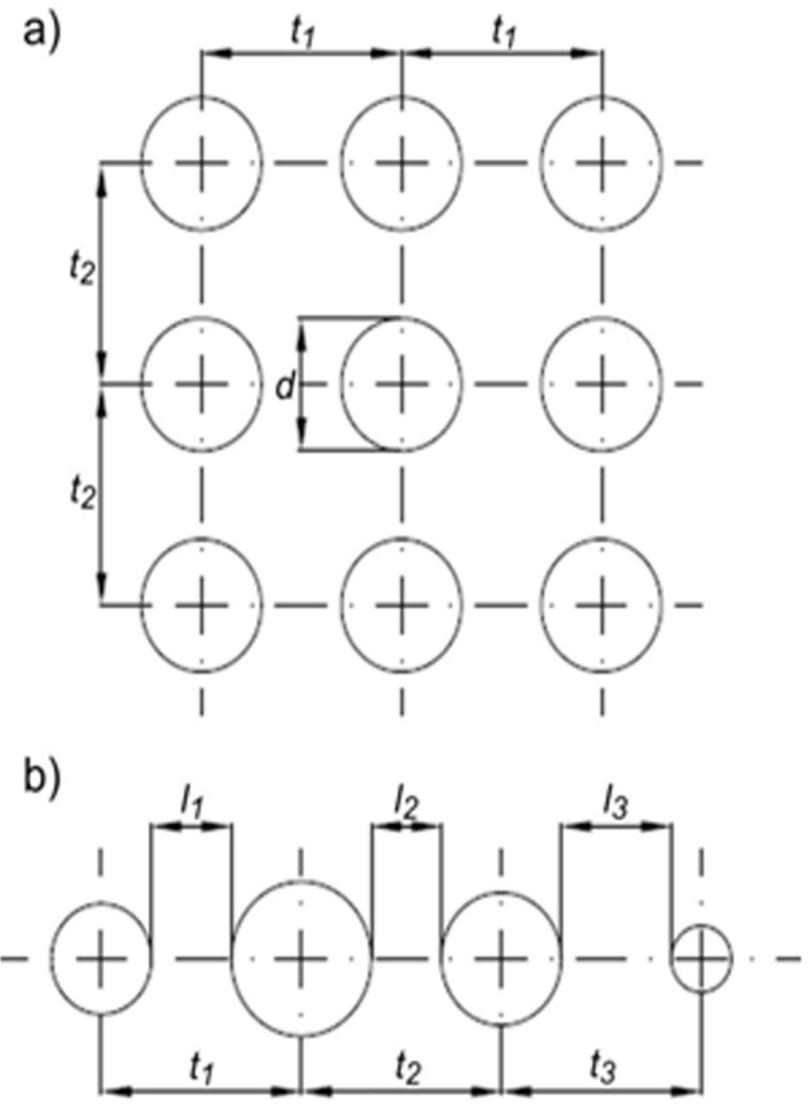

c)

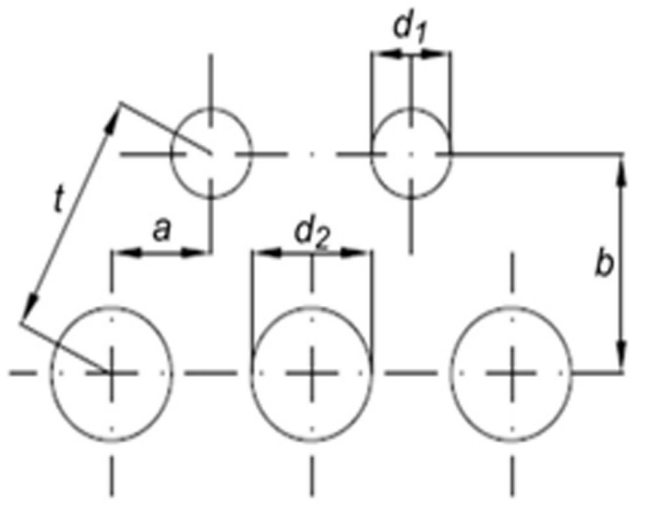

Rys. 1. Rozstawienia otworów w zbiornikach ciśnieniowych i ich wielkości charakterystyczne: a) mostki wzdłużne i obwodowe - takie same średnice i odstępy, b) mostek wzdłużny lub obwodowy - różne średnice i odstępy, c) mostki skośne [8]

Fig. 1. Openings spacing in pressure vessels and their characteristic values: a) longitudinal and circumferential patterns - the same diameters and distances, b) longitudinal or circumferential pattern - different diameters and distances, c) oblique patterns [8]

(dla wyznaczenia wartości pośrednich należy stosować interpolację liniową), w której współczynnik osłabienia określony został na podstawie wskaźnika, określonego wzorem:

gdzie:

$$
\omega=\frac{d}{\sqrt{D_{z} \cdot g_{r z}}}
$$

$d$ - średnica otworu, $\mathrm{mm}$

$D_{z}$ - średnica zewnętrzna zbiornika, $\mathrm{mm}$

$g_{r z}-$ rzeczywista grubość ścianki, $\mathrm{mm}$

Tablica I. Wartość współczynnika osłabienia pojedynczym otworem w zależności od wskaźnika osłabienia [8]

Table I. Weakening coefficient value of single opening depending on weakening rate [8]

\begin{tabular}{|c|c|c|c|c|c|c|c|c|}
\hline$\omega$ & 0 & 0,5 & 1 & 1,5 & 2 & 3 & 4 & 5 \\
\hline$z_{0}$ & 1 & 0,8 & 0,64 & 0,53 & 0,44 & 0,32 & 0,24 & 0,18 \\
\hline
\end{tabular}




\section{Obliczenia współczynnika osłabienia mostkami wzdłużnymi i obwodowymi części walcowej zbiornika}

Podczas wyznaczania współczynnika osłabienia mostkami obwodowymi i wzdłużnymi bierze się pod uwagę otwory, które zostały rozmieszczone promieniowo względem osi (mostki obwodowe) lub równolegle do niej (mostki wzdłużne). Jeżeli w otworze wspawane zostały króćce za pomocą spoin zewnętrznej i wewnętrznej lub spoina jednostronna obejmuje całą grubość materiału, to do obliczeń należy brać pod uwagę średnicę wewnętrzną króćców. Jeżeli wszystkie otwory mają jednakową średnicę, a odstępy pomiędzy nimi są takiej samej długości (rys. 1a), to wartość współczynnika oblicza się ze wzorów [8]:

$$
\begin{aligned}
& z_{1}=\frac{t_{1}-d}{t_{1}} \\
& z_{2}=\frac{t_{2}-d}{t_{2}}
\end{aligned}
$$

gdzie:

$z_{1}$ - współczynnik osłabienia mostkiem wzdłużnym

$z_{2}$ - współczynnik osłabienia mostkiem obwodowym

$t_{1}$ - długość mostka wzdłużnego, mm

$t_{2}$ - długość mostka obwodowego, $\mathrm{mm}$

$d$ - średnica otworu lub średnica wewnętrzna króćca, mm

Jeżeli otwory mają różną średnicę i odległości między nimi nie mają jednakowych wartości (rys. 1b), to współczynniki $z_{1}$ i $z_{2}$ wyznacza się z zależności [8]:

$$
z_{1}, z_{2}=\frac{l_{1}+I_{2}+I_{n}}{t_{1}+t_{2}+t_{n}}
$$

gdzie:

$t_{\mathrm{n}}$ - odległość pomiędzy osiami otworów, mm

$I_{n}$ - odległość mierzona pomiędzy krawędziami sąsiednich otworów w miejscu

W tablicach II i III został przedstawiony wpływ występowania różnych geometrii mostków wzdłużnych i obwodowych. Z uwagi na tożsamość wzorów dla otworów mających jednakową średnicę i odstępy w tabelach zestawiono wyniki dla obu mostków w pojedynczych kolumnach.

Tablica II. Wpływ występowania mostków obwodowych i wzdłużnych na współczynnik osłabienia przy stałej odległości pomiędzy otworami

Table II. Influence of circumferential and longitudinal patterns on weakening coefficient at a constant distance between openings

\begin{tabular}{|c|c|c|}
\hline $\begin{array}{c}\text { Średnica } \\
\text { otworu } d\end{array}$ & $\begin{array}{c}\text { Długość } \\
\text { mostka } t_{1} / t_{2}\end{array}$ & $\begin{array}{c}\text { Współczynnik osłabienia } \\
\text { mostkiem } z_{1} / z_{2}\end{array}$ \\
\hline 100 & 600 & 0,833 \\
\hline 200 & 600 & 0,677 \\
\hline 300 & 600 & 0,5 \\
\hline
\end{tabular}

Tablica III. Wpływ występowania mostków obwodowych i wzdłużnych na współczynnik osłabienia przy stałej odległości pomiędzy otworami

Table III. Influence of circumferential and longitudinal patterns on weakening coefficient at a constant distance between openings

\begin{tabular}{|c|c|c|}
\hline $\begin{array}{c}\text { Średnica } \\
\text { otworu d }\end{array}$ & $\begin{array}{c}\text { Długość } \\
\text { mostka } t_{1} / t_{2}\end{array}$ & $\begin{array}{c}\text { Współczynnik osłabienia } \\
\text { mostkiem } z_{1} / z_{2}\end{array}$ \\
\hline 100 & 200 & 0,5 \\
\hline 100 & 300 & 0,677 \\
\hline 100 & 400 & 0,75 \\
\hline
\end{tabular}

Z tablicy II wynika, że większy wymiar średnicy otworu powoduje obniżenie współczynnika osłabienia mostkiem. Taki sam wpływ ma redukcja odległości między mostkami (tabl. III). Jest to wynik spodziewany i zgodny z praktyką inżynierską. Projektanci urządzeń ciśnieniowych zwykle nie mają możliwości modyfikowania wymiarów przyłączy, zatem w przypadku konieczności redukcji grubości ścianki mogą wykonać adaptacje skutkujące zwiększeniem odległości między otworami.

\section{Obliczenia współczynnika osłabienia mostkami skośnymi części walcowej zbiornika}

Zgodnie z założeniami zawartymi w [8] mostki skośne podczas obliczeń redukuje się na kierunek wzdłużny. W tym celu wprowadza się dwa parametry oznaczone we wzorach, jako $m$ i $t_{\mathrm{s}}$. Pierwszy $z$ nich jest stosunkiem przyprostokątnych trójkąta utworzonego przez odległości pomiędzy otworami w kierunku wzdłużnym i obwodowym. Drugi natomiast jest długością przeciwprostokątnej trójkąta (rys. 1c). Współczynnik osłabienia mostkami skośnymi wyznacza się na podstawie następujących wzorów [8]:

$$
\begin{gathered}
m=\frac{b}{a} \\
t_{\mathrm{s}}=\sqrt{\mathrm{a}^{2}+\mathrm{b}^{2}} \\
K=\frac{1+m^{2}}{\sqrt{\left(1+0,5 \cdot m^{2}\right)^{2}+m^{2}}} \\
z_{\mathrm{s}}=\frac{t_{\mathrm{s}}-0,5 \cdot\left(\mathrm{d}_{1}+\mathrm{d}_{2}\right)}{t_{\mathrm{s}}} \\
z_{\text {red }}=K \cdot z_{\mathrm{s}}
\end{gathered}
$$

gdzie:

$z_{s}-$ współczynnik osłabienia mostkiem skośnym

$z_{\text {red }}$ - współczynnik zredukowany na kierunek wzdłużny

$K$ - współczynnik redukujący osłabienie mostkiem skośnym do wzdłużnego

$t_{\mathrm{s}}$ - długość przyprostokątnej trójkąta, $\mathrm{mm}$

$\mathrm{a}$ - odległość w kierunku wzdłużnym, $\mathrm{mm}$

b - odległość w kierunku obwodowym, $\mathrm{mm}$

$d_{1}, d_{2}$ - średnice otworów, $\mathrm{mm}$

W tablicy IV przedstawiono wpływ różnych zależności wymiarowych ułożenia i średnic otworów, pomiędzy którymi występuje mostek skośny, na współczynnik wytrzymałościowy. Na jej podstawie można wnioskować, jak zmieniają się warunki naprężeniowe w dwóch wariantach: przy zmiennej średnicy i stałej odległości pomiędzy otworami (rys. 2a) oraz przy stałej średnicy i zmiennej odległości pomiędzy otworami (rys. 2b).

Analizując wyniki zawarte w tablicy IV oraz sporządzone na jej podstawie wykresy (rys. 2) można zauważyć, że podobnie do wcześniejszych obliczeń mostków wzdłużnych i obwodowych, wartość współczynnika osłabienia maleje wraz ze wzrostem średnicy otworów, przy tej samej odległości pomiędzy nimi. Zauważono, że zmiana ta ma charakter linowy (np. w każdym przypadku dla $a / b=2 d_{1} / d_{2}$ współczynnik przyjmuje wartość 0,72 ). Osłabienie wytrzymałości konstrukcji zachodzi nawet w przypadku, kiedy tylko średnica otworów w jednym z rzędów się zmienia, natomiast w drugim jest stała. Analogicznie dzieje się, w przypadku stałej średnicy, a zredukowanej odległości między łącznikami. Można też zauważyć, że w niektórych przypadkach wartość współczynnika osłabienia może być niższa od wartości dopuszczalnej. Ma to miejsce, gdy wymiar średnicy jest zbliżony lub większy od odległości między otworami. Wymaga to od projektanta wprowadzenia zmian w geometrii zbiornika (redukcję średnicy, lub jeśli nie jest to możliwe zwiększenie odstępu między otworami). Również 
Tablica IV. Wpływ mostków skośnych na współczynnik osłabienia przy różnych wymiarach średnicy i odległości pomiędzy otworami Table IV. Influence of oblique patterns on weakening coefficient at various dimensions of diameter and distance between openings

\begin{tabular}{|c|c|c|}
\hline $\begin{array}{l}\text { Średnica } \\
\text { otworów } \\
d_{1}=d_{2}, \mathrm{~mm}\end{array}$ & $\begin{array}{l}\text { Odległość } \\
\text { otworów } \\
a=b, \mathrm{~mm}\end{array}$ & $\begin{array}{c}\text { Współczynnik } \\
\text { osłabienia mostkiem } \\
\text { skośnym } z_{\text {red }}\end{array}$ \\
\hline \multirow{5}{*}{50} & 50 & - \\
\hline & 100 & 0,72 \\
\hline & 150 & 0,85 \\
\hline & 200 & 0,91 \\
\hline & 250 & 0,95 \\
\hline \multirow{8}{*}{100} & 100 & - \\
\hline & 150 & 0,59 \\
\hline & 200 & 0,72 \\
\hline & 250 & 0,8 \\
\hline & 300 & 0,85 \\
\hline & 800 & 1,01 \\
\hline & 900 & 1,02 \\
\hline & 1000 & 1,03 \\
\hline \multirow{5}{*}{150} & 150 & - \\
\hline & 200 & 0,52 \\
\hline & 250 & 0,64 \\
\hline & 300 & 0,72 \\
\hline & 350 & 0,77 \\
\hline \multirow{5}{*}{200} & 200 & - \\
\hline & 250 & 0,48 \\
\hline & 300 & 0,59 \\
\hline & 350 & 0,66 \\
\hline & 400 & 0,72 \\
\hline
\end{tabular}

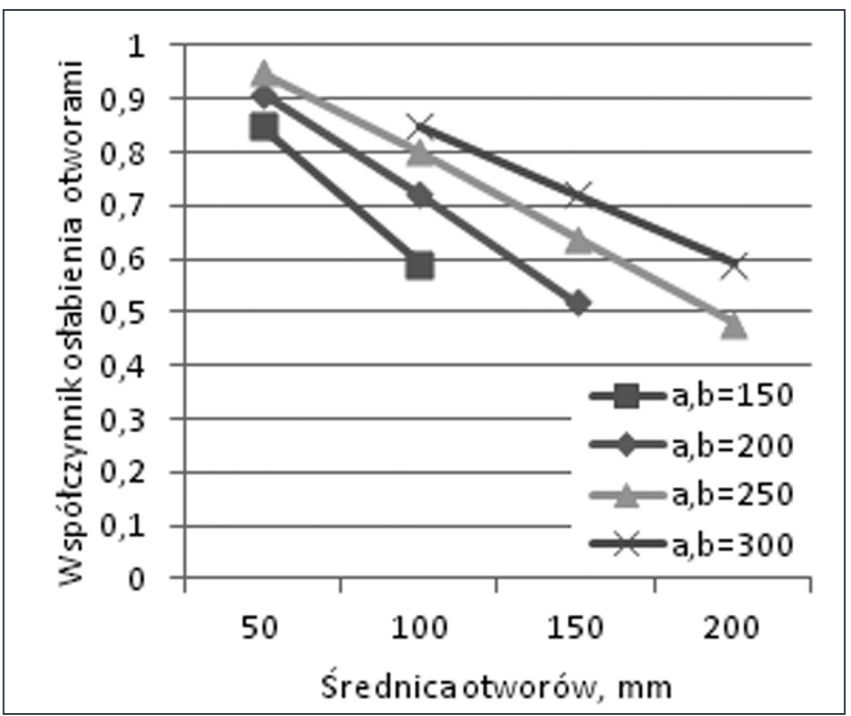

interesującą sytuacją jest przypadek, gdy obliczony współczynnik osłabienia przybiera wartość większą od jedności (duże odstępy przy niewielkich wymiarach średnic). Należy taki wynik interpretować wprost - zadany układ geometryczny nie powoduje osłabienia konstrukcji, co nie zwalnia z konieczności przeprowadzenia obliczeń dla każdego z otworów osobno i wyznaczenia współczynników $z_{0}$. Analogiczna sytuacja (współczynnik osłabienia >1) nie ma miejsca dla mostków wzdłużnych i obwodowych.

\section{Obliczanie współczynników wytrzymałościowych dla wybranych przypadków konstrukcyjnych}

W zbiornikach ciśnieniowych często występują otwory umieszczone w układzie konstrukcyjnym uniemożliwiającym wyliczenia współczynnika na podstawie jednej zależności. Należy w takim przypadku wykonać obliczenia dla wszystkich możliwych wariantów mostków, wybrać najbardziej krytyczną (najmniejszą) wartość współczynnika osłabienia i porównać ją z wynikiem dla każdego pojedynczego otworu. Na rysunku 3a zobrazowano przykładowy układ otworów pod łączniki, dla którego wykonano analizę (wersja I). Dla porównania zmodyfikowano go zmniejszając obwodową odległość między otworami (wersja II - rys. 3b) oraz zwiększając dwukrotnie średnicę otworów (wersja III - rys. 3c). W celu wyraźniejszego uwidocznienia kluczowych parametrów wpływających na osłabienie konstrukcji każdą z trzech wersji dodatkowo zmodyfikowano wymiarowo, uzyskując kombinację 9 przypadków obliczeniowych (tabl. V). Uwzględniono wszystkie rodzaje mostków występujące w tym układzie i porównano wartości współczynników dla najbardziej niekorzystnej sytuacji.

Analiza potwierdza, że bardzo duży wpływ na osłabienie mostkami ma średnica otworów, które go tworzą. Po dwukrotnym zwiększeniu jej wartości wszystkie wyznaczane współczynniki znacząco zmalały. Podobnie jest w przypadku zmniejszania długości mostków. W każdym rozpatrywanym przypadku stwierdzono, że wraz ze zmniejszaniem odległości pomiędzy otworami obniża się wartość współczynnika, a co za tym idzie rośnie wymagana grubość ścianki zbiornika. Osłabienie otworami rozmieszczonymi w rzędzie jest wyznaczane ze średniej długości mostka, dlatego wyniki obliczeń są korzystniejsze w stosunku do współczynników wyznaczanych dla pojedynczych mostków.

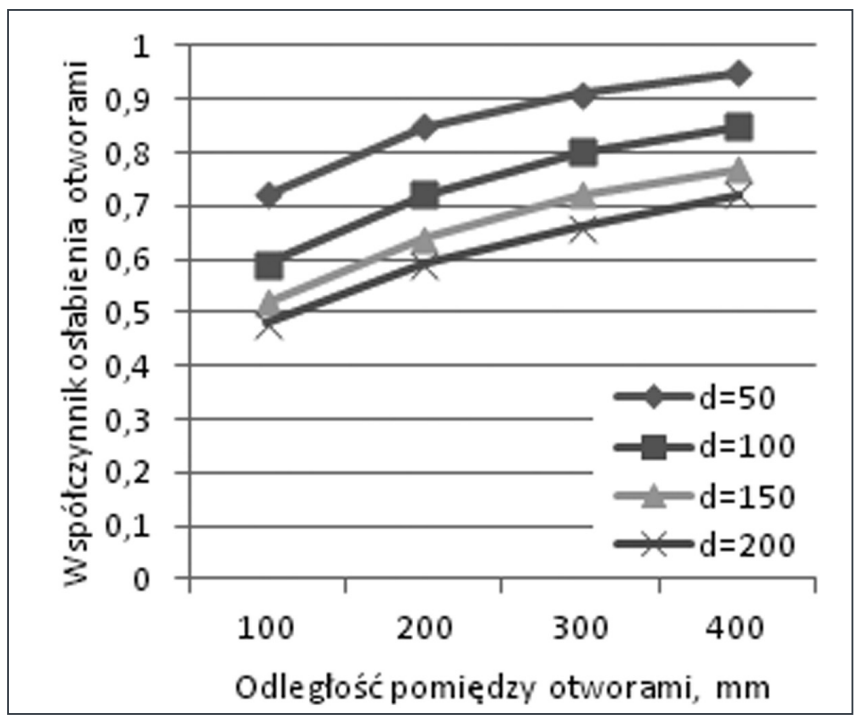

Rys. 2. Wpływ średnicy (a) i odległości między otworami (b) na wartość współczynnika osłabienia

Fig. 2. Effect of diameter (a) and distances between the openings (b) on a value of weakening coefficient 
Tablica V. Wyniki obliczeń współczynników osłabienia dla wybranych wersji kształtowo-wymiarowych mostków Table V. Results of calculation of weakening coefficients for selected form-dimensional versions of patterns

\begin{tabular}{|c|c|c|c|c|}
\hline $\begin{array}{l}\text { Kształt i wymiary } \\
\text { mostka, mm }\end{array}$ & $\begin{array}{c}\text { Współczynnik } \\
\text { osłabienia mostkiem } \\
\text { skośnym }\end{array}$ & $\begin{array}{c}\text { Współczynnik } \\
\text { osłabienia mostkiem } \\
\text { wzdłużnym }\end{array}$ & $\begin{array}{c}\text { Współczynnik } \\
\text { osłabienia mostkiem } \\
\text { obwodowym }\end{array}$ & $\begin{array}{c}\text { Współczynnik } \\
\text { osłabienia otworami } \\
\text { w rzędzie }\end{array}$ \\
\hline $\begin{array}{l}\text { wersja I mostek } \\
200 \times 300\end{array}$ & 1,076 & 0,750 & 0,833 & \multirow{3}{*}{0,750} \\
\hline $\begin{array}{c}\text { wersja I mostek } \\
150 \times 300\end{array}$ & 1,180 & 0,667 & 0,833 & \\
\hline $\begin{array}{l}\text { wersja I mostek } \\
250 \times 300\end{array}$ & 1,014 & 0,800 & 0,833 & \\
\hline $\begin{array}{l}\text { wersja II mostek } \\
200 \times 100\end{array}$ & 0,788 & 0,750 & 0,500 & \multirow{3}{*}{0,750} \\
\hline $\begin{array}{c}\text { wersja II mostek } \\
150 \times 100\end{array}$ & 0,750 & 0,667 & 0,500 & \\
\hline $\begin{array}{l}\text { wersja II mostek } \\
250 \times 100\end{array}$ & 0,820 & 0,800 & 0,500 & \\
\hline $\begin{array}{l}\text { wersja III mostek } \\
200 \times 300\end{array}$ & 0,903 & 0,500 & 0,667 & \multirow{3}{*}{0,500} \\
\hline $\begin{array}{l}\text { wersja III mostek } \\
150 \times 300\end{array}$ & 0,973 & 0,333 & 0,667 & \\
\hline $\begin{array}{c}\text { wersja III mostek } \\
250 \times 300\end{array}$ & 0,866 & 0,600 & 0,667 & \\
\hline
\end{tabular}

a)

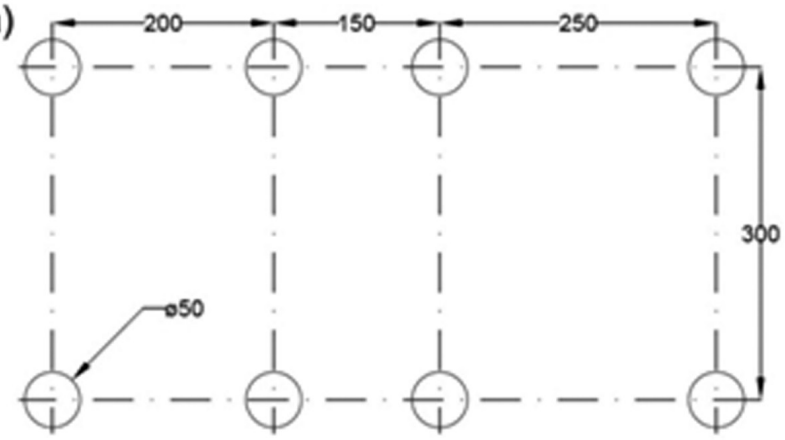

b)

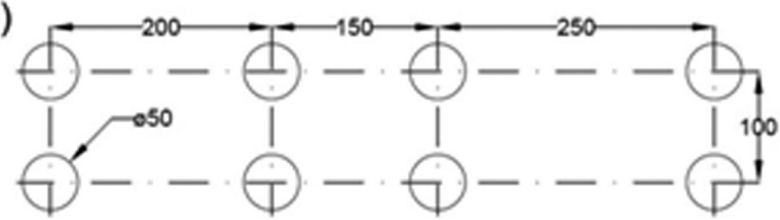

c)
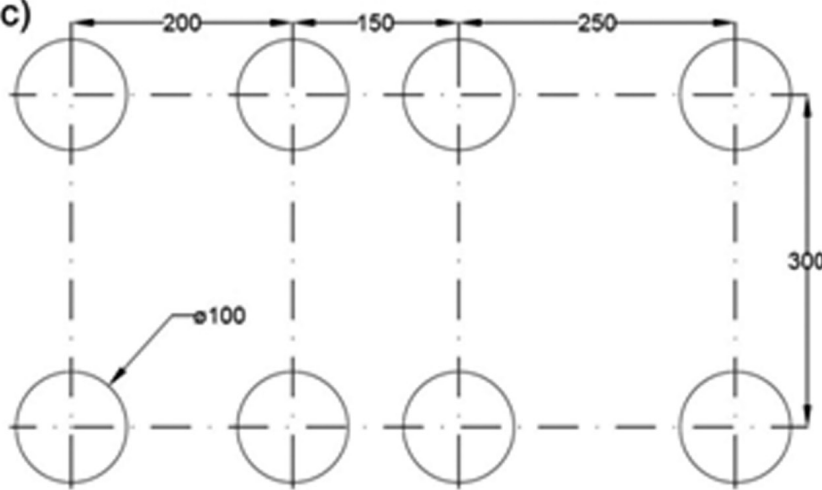

Rys. 3. Przypadki rozmieszczenia otworów w płaszczu zbiornika Fig. 3. Cases of openings spacing in a vessel shell

\section{Obliczenia współczynnika osłabienia włazami rewizyjnymi i wyczystkami w części walcowej zbiornika}

Grubość ścianki potrzebna do wyznaczenia wskaźnika osłabienia jest wartością założoną na początku obliczeń. Bardzo często przypadkiem pojedynczych otworów w zbiorniku są otwory inspekcyjne. Każdy zbiornik (z kilkoma wyjątkami), powinien być obowiązkowo wyposażony w otwory umożliwiające jego przeglądy, naprawy oraz demontaż elementów umieszczonych w jego wnętrzu [8].

Formuła obliczeniowa umożliwia uwzględnienie włazów rewizyjnych w konstrukcji zbiornika ciśnieniowego. W tablicy VI przedstawiono wyniki analizy osłabienia płaszcza tego typu otworami dla trzech najpopularniej stosowanych średnic włazów.

Tablica VI. Wartości współczynnika osłabienia włazem rewizyjnym Table VI. Values of weakening coefficient of inspection manhole

\begin{tabular}{|c|c|c|}
\hline $\begin{array}{c}\text { Średnica } \\
\text { włazu, } \mathrm{mm}\end{array}$ & $\begin{array}{c}\text { Współczynnik } \\
\text { osłabienia włazem } z_{o}\end{array}$ & $\begin{array}{c}\text { Obliczeniowa grubość } \\
\text { ścianki } g_{o,} \mathrm{~mm}\end{array}$ \\
\hline 300 & 0,444 & 13,79 \\
\hline 400 & 0,383 & 16,01 \\
\hline 500 & 0,329 & 18,66 \\
\hline
\end{tabular}

Na podstawie wyników zamieszczonych w tabeli 6 można zauważyć, że współczynnik osłabienia włazem niekorzystnie spada wraz ze wzrostem średnicy. Wartość współczynnika jest silnie uzależniona od cech geometrycznych zbiornika, które zostały założone na początku obliczeń. Dla zbiornika będącego przykładem obliczeniowym z zaprojektowanym włazem o średnicy $300 \mathrm{~mm}$ współczynnik 
osłabienia wynosi 0,444 przy wymaganej grubości ścianki $13,79 \mathrm{~mm}$. Dodatkowe obliczenia wykazały, że zwiększenie średnicy naczynia do 2000 mm, przy tej samej średnicy włazu, powoduje wzrost współczynnika do wartości 0,51, ale również zwiększenie wymaganej grubości ścianki do $15,99 \mathrm{~mm}$. Jest to spowodowane faktem silnego uzależnienia grubości płaszcza zbiornika od jego średnicy [7], w związku z czym jej zmiana o 500 mm ma większy wpływ na zmiany w projektowanej konstrukcji, niż wzrost współczynnika osłabienia włazem. Zmniejszenie średnicy zbiornika o $500 \mathrm{~mm}$ daje podobny efekt, ponieważ pomimo niekorzystnego spadku wartości współczynnika osłabienia włazem do 0,355, obliczeniowa grubość ścianki maleje do wartości 11,51 mm.

W przypadku dwóch odosobnionych otworów o większej średnicy (np. wyczystek lub jakichkolwiek innych otworów pod łączniki wielkogabarytowe), formuła umożliwia także wyznaczenie współczynnika wytrzymałościowego. Jest to szczególny przypadek rozmieszczenia mostka wzdłużnego, obwodowego, bądź skośnego, w przypadku którego, ze względu na duże odległości (WUDT-UC nie definiują ich minimalnych wartości) do obliczeń współczynnika stosuje się inne wzory od wcześniej podanych. W tablicy VII zamieszczono przykładowe wyniki określające wartość współczynnika osłabienia mostkiem odosobnionym wzdłużnym (najkorzystniejsza konstrukcyjnie wersja). Wpływ osłabienia dla otworów o średnicy 300 mm przy odległości 4000 $\mathrm{mm}$ jest niewielki (współczynnik wytrzymałościowy zbliżony do jedności). Zwiększenie średnicy o ponad $65 \%$ również nie powoduje znaczącej redukcji wartości współczynnika. Większy wpływ odnotowano dopiero po wprowadzeniu do formuły średnicy $1000 \mathrm{~mm}$, która w praktyce w zbiorniku o projektowanych gabarytach nie występuje. Dla dwóch wyczystek rozmieszczonych obwodowo na płaszczu badanego zbiornika przesuniętych względem siebie o kąt $180^{\circ}$ (tabl. VIII), współczynnik przyjmuje inne wartości dla tych samych średnic. Nie jest to spowodowane różnicą stałego mnożnika średnicy we wzorze (0,6 - mostek wzdłużny, 0,5 - mostek obwodowy [8]), ale przede wszystkim mniejszą odległością pomiędzy otworami. Można zatem stwierdzić, że zasadne jest sprawdzanie współczynników osłabienia dwoma odosobnionymi otworami, tylko kiedy ich średnica jest znacząca w porównaniu z wymiarami zbiornika, a ich odległość jest niewielka.

Tablica VII. Wpływ osłabienia otworami odosobnionymi - mostek wzdłużny

Table VII. Influence of isolated openings weakening - longitudinal pattern

\begin{tabular}{|c|c|c|}
\hline $\begin{array}{c}\text { Odległość } \\
\text { między otworami } \\
t, \mathrm{~mm}\end{array}$ & $\begin{array}{c}\text { Średnica } \\
\text { otworów } \\
d_{1}=d_{2}, \mathrm{~mm}\end{array}$ & $\begin{array}{c}\text { Wartość } \\
\text { współczynnika } \\
\text { osłabienia } z_{1}\end{array}$ \\
\hline 4000 & 300 & 0,969 \\
\hline 4000 & 500 & 0,946 \\
\hline 4000 & 1000 & 0,882 \\
\hline
\end{tabular}

Tablica VIII. Wpływ osłabienia otworami odosobnionymi - mostek obwodowy

Table VIII. Influence of isolated openings weakening - circumferential pattern

\begin{tabular}{|c|c|c|}
\hline $\begin{array}{c}\text { Odległość } \\
\text { między otworami } \\
t, \mathrm{~mm}\end{array}$ & $\begin{array}{c}\text { Średnica } \\
\text { otworów } \\
d_{1}=d_{2}, \mathrm{~mm}\end{array}$ & $\begin{array}{c}\text { Wartość } \\
\text { współczynnika } \\
\text { osłabienia } z_{2}\end{array}$ \\
\hline 2355 & 300 & 0,932 \\
\hline 2355 & 500 & 0,881 \\
\hline 2355 & 1000 & 0,73 \\
\hline
\end{tabular}

\section{Wpływ osłabienia otworami dna wypukłego na grubość jego ścianki}

Jak wykazano w [7], zwiększenie wartości średnicy oraz wysokości dna wypukłego, tak jak w przypadku części walcowej zbiornika, powoduje wzrost wymaganej grubości ścianki. Dla zastosowanych parametrów konstrukcyjnych sprawdzono wpływ osłabienia dennicy otworem oraz określono obszar dna, w jakim może być wykonany. Do obliczeń przyjęto dennicę wypukłą o średnicy wewnętrznej $D_{\mathrm{w}}=2000 \mathrm{~mm}$ i wysokości $600 \mathrm{~mm}$, poddaną ciśnieniu $1 \mathrm{MPa}$. Promienie wypukłości i wyoblenia wynoszą odpowiednio 1789 i $288 \mathrm{~mm}$. Otwory zaprojektowano centralnie w dnie. Obliczona odległość krawędzi otworu od krawędzi dna nie mogła być mniejsza niż 201 mm, zatem w każdym przypadku warunek ten został spełniony. Wyniki przedstawione w tablicy IX potwierdzają, że oprócz ustalonych gabarytów zbiornika, zwiększająca się średnica otworu wykonanego w dnie powoduje wzrost grubości jego ścianki.

Tablica IX. Wpływ występowania otworów w dennicy wypukłej na jej grubość

Table IX. Influence of openings occurrence in dished head on its thickness

\begin{tabular}{|c|c|}
\hline Średnica otworu, $\mathrm{mm}$ & Grubość ścianki dna, mm \\
\hline 100 & 5 \\
\hline 200 & 6 \\
\hline 300 & 8 \\
\hline 400 & 8 \\
\hline 500 & 9 \\
\hline
\end{tabular}

\section{Wpływ osłabienia otworami dna płaskiego na grubość jego ścianki}

Podobnie jak w przypadku dennic wypukłych, wpływ projektowania otworów sprawdzono także dla den płaskich. Wyniki przedstawione w tablicy IX dotyczą ich dwóch wersji kształtowych: wyoblonych oraz bez wyoblenia, łączonych z płaszczem spoiną obustronną. W tym przypadku podano obliczeniową grubość ścianki, gdyż zależności arytmetyczne wykorzystane w analizie nie uwzględniają wpływającej na wyniki zakładanej na początku obliczeń grubości. Ciśnienie obliczeniowe i średnicę przyjęto tożsame z wcześniej analizowanym dnem wypukłym. Obliczeniowa grubość ścianki dna nieosłabionego otworem w tych warunkach pracy wyniosła $g_{0}=43,91 \mathrm{~mm}$ (bez wyoblenia) oraz $45,5 \mathrm{~mm}$ (z wyobleniem). Analizując wyniki przedstawione $w$ tablicy $X$ można zauważyć, że obecność otworu umieszczonego poza wyznaczonym w trakcie obliczeń pierścieniem o średnicach 1000 i 2000 mm, nie ma tak znaczącego wpływu na grubość ścianki dna, jak sama geometria naczynia. Radykalna zmiana średnicy otworu (o 100\%), powoduje przyrost zapotrzebowania na grubość ścianki o średnio ok. 1,5 mm, niezależne od kształtu dna (uwzględniając nawet dna wypukłe - tabl. IX).

Tablica X. Grubość ścianki dna płaskiego z wyobleniem i bez wyoblenia w zależności od średnicy otworu

Table X. Wall thickness of flat head with knuckle and without knuckle depending on opening diameter

\begin{tabular}{|c|c|c|}
\hline $\begin{array}{c}\text { Średnica } \\
\text { otworu, } \mathrm{mm}\end{array}$ & $\begin{array}{c}\text { Grubość ścianki dna } \\
\text { z wyobleniem, } \mathrm{mm}\end{array}$ & $\begin{array}{c}\text { Grubość ścianki dna } \\
\text { bez wyoblenia, } \mathrm{mm}\end{array}$ \\
\hline 100 & 45,05 & 46,68 \\
\hline 200 & 46,28 & 47,96 \\
\hline 300 & 47,63 & 49,35 \\
\hline 400 & 49,09 & 50,87 \\
\hline 500 & 50,7 & 52,54 \\
\hline
\end{tabular}




\section{Wzmocnienia króćców w części walcowej i dennicy}

Wzmocnienia króćców stosuje się w celu zredukowania grubości ścianki całego zbiornika $[4-6,8,10,11]$. Lokalne nakładki wzmacniające umożliwiają wygenerowanie znacznych oszczędności, dzięki możliwości zastosowania w konstrukcji grubości ścianki liczonej dla urządzenia bez otworów. Istnieją zależności geometryczne definiujące konieczność stosowania wzmocnień dla określonych średnic otworów [5]. Obliczenie wzmocnienia ścianki osłabionej otworem polega na ustaleniu i porównaniu ilości materiału straconego, z ilością materiału wzmacniającego. Zespół ścianka zbiornika - wzmocnienie musi tworzyć całość pod względem wytrzymałościowym, a naprężenia dla założonych parametrów pracy naczynia zawierały się $\mathrm{w}$ przedziale naprężeń dopuszczalnych [6]. Przedmiotem obliczeń jest zbiornik o średnicy wewnętrznej 2000 mm i długości 5000 mm, z 3 króćcami rozmieszczonymi rzędowo w płaszczu i dwoma centralnie w wypukłych dennicach (rys. 4), którego stateczność sprawdzano w [7]. Dla tak zaprojektowanego urządzenia ciśnieniowego przeprowadzono pełną analizę obliczeniową, której interesujące z punktu widzenia wzmocnień króćców wyniki zestawiono w tablicy XI.

Analizując wyniki zawarte w tablicy XI można zauważyć, że stosowanie wzmocnień może znacząco wpłynąć na grubość ścianki zbiornika. W przypadku części walcowej zbiornika udało się ją zredukować aż o $8 \mathrm{~mm}$ i zastosować jedynie miejscowe wzmocnienia o grubości $6 \mathrm{~mm}$. Jak widać z prezentowanych wyników obliczeń, wymiary wzmocnienia są mniejsze, niż wymiar, o który pomniejszona została grubość ścianki. Można zatem stwierdzić, że nakładki wzmacniające kompensują lokalnie naprężenia wynikające z obecności otworów, ale gabarytowo nie zawsze odzwierciedlają dokładnie stan obliczeniowy dla pełnej grubości ścianki. Często ich wymiar jest mniejszy od „zaoszczędzonej” grubości ścianki. Grubości króćców są zbliżone wymiarami do grubości elementów, z którymi będą połączone, co jest zgodne z zaleceniami zawartymi w WUDT-UC [8]. W przypadku dennicy również udało się zredukować grubość ścianki o $3 \mathrm{~mm}$. Wzmocnienie miejscowe $w$ tym przypadku powinno mieć grubość $3 \mathrm{~mm}$. Wymiary podane w nawiasach są grubościami obliczeniowymi, które został powiększone o naddatki technologiczne, eksploatacyjne oraz konstrukcyjne.

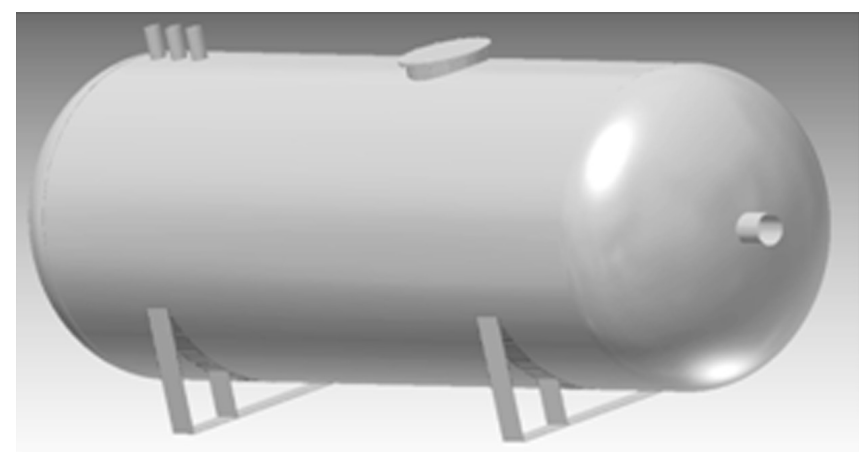

Rys. 4. Konstrukcja zbiornika ciśnieniowego zastosowanego jako przykład obliczeniowy

Fig. 4. Construction of pressure vessel used as a calculation example

Tablica XI. Wyniki obliczeń grubości ścianek zbiornika osłabionego otworami Table XI. Results of wall thickness calculation of openings weakened vessel

\begin{tabular}{|c|c|c|}
\hline Przyjęta (obliczona) grubość ścianki części walcowej z uwzględnieniem otworów & $14(12,56)$ & $\mathrm{mm}$ \\
\hline Przyjęta (obliczona) grubość ścianki dennic z uwzględnieniem otworów & $8(6,18)$ & $\mathrm{mm}$ \\
\hline Przyjęta (obliczona) grubość ścianki części walcowej bez otworów & $6(4,05)$ & $\mathrm{mm}$ \\
\hline Przyjęta (obliczona) grubość ścianki dennic bez otworów & $5(3,05)$ & $\mathrm{mm}$ \\
\hline $\begin{array}{l}\text { Przyjęta grubość ścianki króćca } \\
\text { w dennicy }\end{array}$ & $5(0,34)$ & $\mathrm{mm}$ \\
\hline $\begin{array}{l}\text { Przyjęta grubość ścianki króćca } \\
\text { o średnicy } 100 \text { mm }\end{array}$ & $5(4,056)$ & $\mathrm{mm}$ \\
\hline Przyjęta grubość ścianki włazu & $5(4,056)$ & $\mathrm{mm}$ \\
\hline $\begin{array}{l}\text { Grubość wzmocnienia } \\
\text { w części walcowej }\end{array}$ & 6 & $\mathrm{~mm}$ \\
\hline Grubość wzmocnienia dennicy & 3 & $\mathrm{~mm}$ \\
\hline
\end{tabular}




\section{Wnioski}

Na podstawie analiz przeprowadzonych z wykorzystaniem opracowanej formuły obliczeniowej bazującej na treści WUDT, sformułowano następujące wnioski dotyczące konstruowania zbiorników ciśnieniowych:

- Obliczenia przeprowadzone dla mostków wzdłużnych, obwodowych i skośnych wykazały, że wartość współczynnika osłabienia otworami maleje wraz ze wzrostem średnicy otworów, natomiast wzrasta dla większych odległości między środkami ich osi. Skutkuje to koniecznością zastosowania większej grubości ścianki, silnie uzależnionej od cech geometrycznych zbiornika, które zostały założone na początku obliczeń. Dodatkowe obliczenia wykazały, że zwiększenie średnicy naczynia, przy tej samej średnicy włazu, powoduje wzrost współczynnika osłabienia, ale również zwiększenie wymaganej grubości ścianki.

- W przypadku dennic, podobnie do części walcowej zbiornika, potwierdzono, że zwiększająca się średnica wykonanego otworu skutkuje wzrostem grubości jego ścianki. Należy przy tym stwierdzić, że obecność otworu w tej części urządzenia ciśnieniowego, nie ma aż tak znaczącego wpływu na grubość ścianki, jak sama geometria dna. Dla wybranego przykładu obliczeniowego, 100\% zmiana średnicy otworu spowodowała przyrost grubości ścianki o średnio ok. 1,5 mm, niezależne od kształtu dennicy (płaska lub wypukła).

- Zasadne jest sprawdzanie współczynników osłabienia dwoma odosobnionymi otworami, tylko kiedy ich średnica jest znacząca w porównaniu z wymiarami zbiornika, a ich odległość jest niewielka.

- Stosowanie wzmocnień otworów pod łączniki może znacząco wpłynąć na grubość ścianki zbiornika. W zależności od wymiarów i parametrów pracy urządzenia istnieje możliwość jej redukcji od kilku do kilkunastu milimetrów. Dodatkowo wykazano, że wymiary wzmocnienia są mniejsze, niż wymiar, o który pomniejszona została grubość ścianki. Można zatem stwierdzić, że nakładki wzmacniające kompensują lokalnie naprężenia wynikające z obecności otworów, ale gabarytowo nie zawsze odzwierciedlają dokładnie stan obliczeniowy dla pełnej grubości ścianki.

- Opracowana formuła obliczeniowa daje możliwości kompetentnego, a przede wszystkim szybkiego optymalizowania wymiarów zbiorników ciśnieniowych, co w efekcie pozwala na sprawdzenie wielu rozwiązań konstrukcyjnych zbiorników oraz wyboru najkorzystniejszego strukturalnie i najbardziej ekonomicznego. Zredukowana grubość ścianki zbiorników ciśnieniowych to nie tylko oszczędności materiałowe, ale również kompresja czasu produkcyjnego oraz uproszczenie technologii wytwarzania.

\section{Literatura}

[1] Dyrektywa 2014/68/UE Parlamentu Europejskiego i Rady w sprawie harmonizacji ustawodawstw Państw Członkowskich odnoszących się do udostępnienie na rynku urządzeń ciśnieniowych, 15.05.2014.

[2] Dyrektywa 97/23/WE Parlamentu Europejskiego i Rady w sprawie zbliżenia ustawodawstw Państw Członkowskich dotyczących urządzeń ciśnieniowych, 29.05.1997.

[3] Dyrektywy urządzenia ciśnieniowe 97/23/WE oraz proste zbiorniki ciśnieniowe 2009/105/WE, broszura informacyjna, Projekt PL 0426: Wsparcie administracji publicznej, organizacji pozarządowych i organizacji przedsiębiorców w procesie upowszechniania wśród małych i średnich przedsiębiorstw wiedzy na temat Dyrektyw Nowego i Globalnego Podejścia, Warszawa 2010.

[4] Ferenc K., Ferenc J.: Konstrukcje spawane, Połączenia, WNT, Warszawa 2006.

[5] Sędek P.: Projektowanie urządzeń ciśnieniowych, Materiały szkoleniowe: Kurs Międzynarodowego Inżyniera Spawalnika, Instytut Spawalnictwa, Gliwice 2012.
[6] Dudek A., Łaczek S.: Zbiornik ciśnieniowy spawany, materiały pomocnicze do projektu z podstaw konstrukcji maszyn, Wyd. Politechniki Krakowskiej, Kraków 2006.

[7] Piwowarczyk T., Nabielec T.: Wpływ zależności kształtowowymiarowych i ciśnienia roboczego na grubość ścianki zbiorników ciśnieniowych projektowanych według WUDT/ UC/2003, Przegląd Spawalnictwa, nr 8/2015.

[8] Warunki Urzędu Dozoru Technicznego WUDT-UC-2003, Wydanie 2, Urząd Dozoru Technicznego, Warszawa 2005.

[9] Dudek J.: Metoda odprężania mechanicznego naczyń ciśnieniowych, Rozprawa doktorska, Politechnika Wrocławska, Raport serii PRE 2/07, Wrocław 2007.

[10] Słania J., Kaczor T.: Plan spawania zbiornika ciśnieniowego, Przegląd Spawalnictwa, nr 4/2010.

[11] Pikoń J.: Podstawy konstrukcji aparatury chemicznej, Elementy aparatury chemicznej, Cześć II, PWN, Warszawa 1979. 